\title{
Efektifitas Pembelajaran Berbasis Masalah dalam Meningkatkan Sikap Kepedulian Lingkungan Siswa (Studi Kasus pada Permasalahan Lingkungan Global)
}

\author{
Dita Agustian $^{a}$, Fransisca Sudargo ${ }^{b}$, Wahyu Surakusumah ${ }^{c}$ \\ ${ }^{a}$ Program Studi Pendidikan Biologi FKIP UNPAS \\ ${ }^{b}$, Program Studi Pendidikan Biologi FPMIPA UPI \\ Email:agustian_dita@yahoo.com
}

\begin{abstract}
Abstrak
Penelitian ini dilakukan atas dasar keprihatinan terhadap perilaku masyarakat yang terkesan acuh terhadap permasalahan lingkungan yang terjadi di lingkungan sekitarnya, serta adanya harapan untuk membentuk generasi muda yang peduli dan memiliki etika lingkungan yang lebih baik. Penelitian ini bertujuan untuk mengetahui efektifitas pembelajaran berbasis masalah dalam meningkatkan sikap kesadaran lingkungan siswa khususnya pada kasus-kasus permasalahan lingkungan global. Metode penelitian ini menggunakan Quasi Experimental dengan desain One Group Pretest-Posttest Design dan pengambilan sampel secara Purposive Sampling. Data diperoleh melalui skala sikap kepedulian lingkungan berdasarkan tingkatan ranah sikap menurut Krathwohl, Bloom, dan Masia. Hasil menunjukkan bahwa model pembelajaran berbasis masalah melalui penggunaan permasalahan lingkungan global, efektif dalam meningkatkan sikap kepedulian lingkungan siswa. Hal ini ditunjukkan dengan nilai indeks gain sebesar 0,52 yang termasuk kategori sedang dan rerata nilai sikap di atas Kriteria Ketuntasan Minimal (KKM) yaitu 81,4. Indikator sikap kesadaran lingkungan yang memiliki nilai paling tinggi yaitu peduli atau sadar dengan nilai 95, dan yang paling rendah yaitu komitmen dengan nilai 55. Hasil penelitian ini diharapkan bisa diimplementasikan di dalam kegiatan pembelajaran sehari-hari untuk membiasakan siswa supaya memiliki kepedulian dan karakter yang baik terhadap lingkungan di sekitarnya.
\end{abstract}

Kata kunci : Efektifitas, Pembelajaran Berbasis Masalah, Kepedulian Lingkungan, dan Permasalahan Lingkungan Global

Isu permasalahan mengenai lingkungan merupakan topik yang tidak pernah lepas dari pemberitaan sampai saat ini, mulai dari tingkat lokal, regional, nasional, maupun internasional. Hal ini dikarenakan kita sebagai manusia akan selalu hidup berdampingan dengan lingkungan di sekitar kita dengan membentuk hubungan saling ketergantungan. Oleh karena itu, untuk senantiasa menjaga keseimbangan hubungan saling ketergantungan tersebut, kita harus senantiasa menjaga kelestarian lingkungan dimanapun kita berada terutama di lingkungan tempat tinggal kita sendiri, sehingga akan tercipta keharmonisan sekaligus turut serta dalam menjaga aset berharga untuk masa depan kita dan keturunan kita. Dengan kata lain, adanya hubungan saling ketergantungan antara manusia dan lingkungannya, membuat lingkungan akan sangat berpengaruh terhadap kualitas kehidupan manusia, sehingga apabila kita menginginkan kualitas hidup yang lebih baik, maka kita semua harus ikut berpartisipasi di dalam menjaga dan melestarikan lingkungan kita.

Akan tetapi, terkadang harapan tidak selalu sesuai dengan kenyataan. Bagi orang tertentu atau pihak yang kurang peduli terhadap lingkungan, pemenuhan kebutuhan seringnya bertolak belakang dengan upaya pelestarian sumber daya alam. Kebutuhan manusia yang semakin meningkat dan bervariasi dari waktu ke waktu, akan berimbas pada eksploitasi sumber daya alam yang semakin meningkat pula. Kondisi ini menuntut kita semua untuk berpikir dan mencari solusi terhadap pemenuhan kebutuhan manusia sekaligus tetap berupaya menjaga dan melestarikan lingkungan untuk keberlangsungan makhluk hidup pada umumnya dan manusia pada khususnya.

Akan tetapi pada kenyataannya, dewasa ini laju kerusakan lingkungan, khususnya di Negara Indonesia malah semakin meningkat. Menurut Irwanto (2013), data dari World Bank mengungkapkan bahwa laju deforestasi di 
Indonesia berkisar antara 700.000 sampai 1,2 juta ha per tahun. Sedangkan menurut FAO, laju kerusakan hutan di Indonesia mencapai 1.315.000 ha per tahun, atau setiap tahunnya luas areal hutan berkurang sebesar satu persen (1\%). Berbagai LSM yang peduli lingkungan, missalnya seperti Greenpeace bahkan mengungkapkan data yang lebih mencengangkan lagi, yaitu bahwa kerusakan hutan di Indonesia mencapai 3,8 juta ha per tahun yang sebagian besar adalah penebangan liar (Irwanto, 2013). Perbedaan data tersebut diakibatkan oleh adanya perbedaan persepsi dan kepentingan dalam mengungkapkan data tentang kerusakan hutan.

Selain itu, aspek lain yang berpengaruh terhadap kelestarian lingkungan adalah adanya fenomena seperti Pemanasan Global (Global Warming). Fenomena ini terjadi karena adanya lapisan gas-gas rumah kaca, seperti uap air, $\mathrm{CH}_{4}, \mathrm{CO}$, dan $\mathrm{CO}_{2}$, yang terdapat di atmosfer, sehingga menghalangi energi panas matahari yang seharusnya dipantulkan kembali ke angkasa. Hal tersebut tentunya akan menyebabkan naiknya temperatur atau suhu bumi, dan memberikan dampak lain yang berkelanjutan. Beberapa ahli biologi, yaitu Solomon, Berg, dan Martin (2008) mengungkapkan data mengenai tingkat konsentrasi berbagai polutan yang termasuk ke dalam gas rumah kaca sebagai berikut.

Tabel 1.1.

Tingkat Konsentrasi Berbagai Gas Rumah Kaca

\begin{tabular}{|c|l|c|c|}
\hline No & Gas & $\begin{array}{c}\text { Perkiraan } \\
\text { sebelum tahun } \\
\mathbf{1 7 5 0}\end{array}$ & Saat ini \\
\hline 1 & $\mathrm{CO}_{2}$ & $280 \mathrm{ppm}$ & $337 \mathrm{ppm}$ \\
\hline 2 & $\mathrm{CH}_{4}$ & $730 \mathrm{ppb}$ & $1847 \mathrm{ppb}$ \\
\hline 3 & $\mathrm{NO}_{2}$ & $270 \mathrm{ppb}$ & $319 \mathrm{ppb}$ \\
\hline 4 & $\mathrm{CFC}-12$ & $0 \mathrm{ppt}$ & $545 \mathrm{ppt}$ \\
\hline 5 & $\mathrm{CFC}-11$ & $0 \mathrm{ppt}$ & $253 \mathrm{ppt}$ \\
\hline
\end{tabular}

Keterangan:

$\mathrm{ppm} \quad=$ part per million

$\mathrm{ppb} \quad=$ part per billion

ppt = part per trilli on

(Sumber: Solomon, Berg, dan Martin, 2008)

Kondisi kerusakan lingkungan yang lain memiliki data yang berbeda. Menurut Natural Resources Defense Council (Lembaga Pertahanan Sumber Daya Alam) Amerika Serikat (2011), mengungkapkan bahwa rata-rata peningkatan suhu di Amerika Serikat berkisar antara $3-9^{\circ} \mathrm{C}$ pada satu abad terakhir ini. Me- nurut hasil penelitiannya, dampak yang terjadi akibat kenaikan suhu ini diantaranya adalah meningkatnya angka kematian akibat suhu ekstrim terutama anak-anak, orang tua, dan orang miskin; meningkatnya penyakit yang ditransmisikan melalui makanan, minuman, dan serangga; serta tidak menentunya pola iklim dan meningkatnya permukaan air.

Kemudian, peningkatan kebutuhan manusia yang disertai dengan perkembangan ilmu pengetahuan dan teknologi, memberikan konsekuensi logis terhadap peningkatan dalam bidang industri dan transportasi. Kedua bidang ini memberikan dampak langsung terhadap meningkatnya tingkat pemanasan global (Global Warming) yang dapat menyebabkan berbagai permasalahan lingkungan yang lebih kompleks. Fenomena berbagai permasalahan lingkungan tersebut semakin diperparah dengan adanya hasil studi yang dilakukan oleh Kementerian Lingkungan Hidup pada tahun 2012 yang menyatakan bahwa Indeks Peduli Lingkungan (IPL) masyarakat Indonesia masih berkisar pada 0,57 dari angka mutlak satu (1). Hal ini mengindikasikan bahwa masyarakat belum berperilaku peduli terhadap lingkungannya. Oleh karena itu, perlu kesadaran semua pihak untuk bersama-sama menjaga dan melestarikan lingkungan demi terciptanya hubungan yang selaras antara manusia dan lingkungannya. Pemahaman dan sikap kepedulian terhadap kelestarian lingkungan tersebut, sangat perlu untuk ditanamkan kepada generasi muda yang akan mewarisi tanggungjawab untuk dapat menjaga, mengelola, serta melestarikan lingkungan secara arif dan bijaksana.

Sebagai upaya atau langkah nyata kita sebagai pendidik dalam menyikapi permasalahan ini adalah dengan menginternalisasikan pemahaman dan sikap tersebut di dalam setiap aktifitas pembelajaran. Lang-kah ini diharapkan mampu menyiapkan peserta didik yang memiliki kesadaran dan kepedulian terhadap lingkungannya, karena aktifitas-aktifitas yang dilakukan di lingkungan sekolah nantinya diharapkan akan menjadi suatu kebiasaan, dan kebiasaan tersebut diharapkan pula akan menjadi sebuah karakter yang melekat kuat pada setiap peserta didik. Salah satu model yang mendukung upaya ini adalah dengan menggunakan model pembelajaran yang berbasis masalah (PBL). Sebagai suatu model, Problem Based Learning (PBL) merupakan salah satu 
upaya dalam kegiatan pembelajaran untuk mengembangkan keterampilan berpikir dan berkomunikasi bagi siswa, karena di dalamnya terdapat berbagai macam interaksi sosiologis antara anggota kelompok maupun antar kelompok, seperti diskusi, berdebat, saling mendukung dan menguatkan pendapat, yang membuat kemampuan siswa terasah dengan baik. Salah satu aspek yang penting dalam kegiatan pembelajaran berbasis masalah adalah proses pemecahan masalah (Problem Solving). Pemecahan masalah didefinisikan sebagai suatu proses penghilangan perbedaan atau ketidaksesuaian yang terjadi antara hasil yang diperoleh dan hasil yang diinginkan. Salah satu bagian dari proses pemecahan masalah adalah pengambilan keputusan (decision making), yang didefinisikan sebagai pemilihan solusi terbaik dari sejumlah alternatif yang tersedia (Cahyadi, 2009).

Penelitian ini difokuskan pada aplikasi yang terintegrasi di dalam aktivitas pembelajaran dengan penggunaan masalah-masalah yang bersifat global sebagai stimulus awal dalam pembelajaran untuk meningkatkan kualitas sikap kepedulian lingkungan siswa. Kategori sikap yang digunakan dalam penelitian ini diambil berdasarkan tingkatan ranah afektif atau sikap menurut Krathwohl, Bloom, dan Masia (1964) yang terdiri dari Menerima, Merespon, Menilai, Mengorganisasi, dan Mengkarakterisasi.

Diharapkan melalui penerapan strategi tersebut di dalam proses pembelajaran di kelas, siswa dapat lebih menyadari keadaan lingkungannya, baik dalam skala global maupun lokal. Selain itu, diharapkan juga siswa mampu mengaplikasikan pemahaman dan sikap kepeduliannya terhadap ling-kungan dalam kehidupan sehari-hari, dan diharapkan generasi muda yang dihasilkan memiliki kecakapan yang sesuai dengan tuntutan yang tercantum dalam Standar Kompetensi Lulusan, khususnya dalam hal sikap mereka dalam memperlakukan lingkungannya. Hal itulah yang mendasari penulis untuk dapat memberikan kontribusi melalui penelitian ini, dengan harapan akan terbentuknya generasi muda yang cerdas dalam menjaga, mengelola, dan melestarikan lingkungannya.

\section{Metodologi}

Penelitian ini menggunakan metode penelitian eksperimen semu (Quasy Ex-periment) dengan desain penelitian One Group PretestPosttest Design. Untuk lebih memperjelas gambaran tentang desain ini, Sugiyono (2009) merangkumnya sebagai berikut:

$\begin{array}{lll}\mathrm{O}_{1} & \mathrm{X}_{1} & \mathrm{O}_{2}\end{array}$

Keterangan:

$\mathbf{O}_{1}$ : pretes

$\mathbf{O}_{2}$ : postes

$\mathbf{X}_{1}$ : perlakuan pembelajaran berbasis masalah dengan menggunakan per-masalahan lingkungan global

Penelitian ini dilaksanakan di salah satu SMA yang terletak di Kota Bandung. Populasi dalam penelitian ini adalah seluruh siswa kelas $X$ SMA X Bandung. Sedangkan sampel yang digunakan dalam penelitian ini adalah siswa kelas X1 di SMA tersebut dengan jumlah siswa 28 orang. Sekolah ini dipilih karena lokasinya yang tidak terlalu jauh dan termasuk salah satu SMA klaster 1 di Kota Bandung. Kemudian untuk pemilihan sampel, teknik yang digunakan adalah pemilihan sampel yang bertujuan (Purposive Sampling).

Instrumen yang digunakan adalah skala sikap dengan jenis Skala Likert untuk mengukur kesadaran lingkungan siswa. Skala sikap ini dikembangkan dari 5 kategori tingkatan ra-nah sikap menurut Krathwohl, Bloom, dan Masia, yaitu Menerima (Peduli atau Sadar, Kesediaan untuk menerima, dan Mengarahkan perhatian); Merespon (Perolehan atau persetu-juan respon, Keinginan untuk merespon, dan Kepuasan dalam merespon); Menilai (Peneri-maan suatu nilai, Kecenderungan pada nilai, dan Komitmen); Mengorganisasi (Konseptua-lisasi nilai dan Organisasi sistem nilai); dan Mengkarakterisasi (Internalisasi semua sistem nilai dan Karakterisasi/perolehan kepribadian)

Untuk menafsirkan hasil pengukuran diperlukan suatu kriteria. Kriteria yang digunakan tergantung pada skala dan jumlah butir pertanyaan/pernyataan yang digunakan. Jumlah pernyataan yang akan digunakan pada skala Likert, berisi 13 butir pernyataan (sesuai dengan jumlah indikator domain sikap menurut Krathwohl, Bloom, dan Masia) dengan empat pilihan untuk mengukur sikap peserta didik. Skor tertinggi untuk instrumen tersebut adalah 13 butir x $4=52$, dan skor terendah 13 butir $\mathrm{x} 1=13$. Skor ini dikualifikasikan menjadi empat kategori sikap atau minat, yaitu sa- 
ngat tinggi (sangat baik), tinggi (baik), rendah (kurang), dan sangat rendah (sangat kurang). Berdasarkan kategori ini dapat ditentukan minat atau sikap peserta didik. Untuk lebih jelasnya, dapat dilihat pada tabel 2.1 di bawah ini:

Tabel 2.1

Skala penilaian angket peserta didik

\begin{tabular}{|l|c|c|}
\hline \multirow{2}{*}{\multicolumn{1}{|c|}{ Alternatif Jawaban }} & \multicolumn{2}{|c|}{ Bobot Penilaian } \\
\cline { 2 - 3 } & $(+)$ & $(-)$ \\
\hline Sangat Tidak Setuju (STS) & 1 & 4 \\
\hline Tidak Setuju (TS) & 2 & 3 \\
\hline Setuju (S) & 3 & 2 \\
\hline Setuju Sekali (SS) & 4 & 1 \\
\hline
\end{tabular}

(Sumber: Ismail, 2012)

Sedangkan untuk penentuan kategori hasil pengukuran sikap kesadaran lingkungan dapat dilihat pada tabel 2.2 berikut.

Tabel 2.2

Kategorisasi sikap atau minat peserta didik serta konversi nilai untuk 13 butir pernyataan, dengan rentang skor 13 52.

\begin{tabular}{|c|c|c|}
\hline No. & Skor & Kategori Sikap atau Minat \\
\hline \hline 1. & $>43$ & Sangat tinggi/Sangat baik \\
\hline 2. & $33-42$ & Tinggi/Baik \\
\hline 3. & $22-32$ & Rendah/Kurang \\
\hline 4. & $<22$ & Sangat rendah/Sangat kurang \\
\hline \multicolumn{2}{|r}{ (Sumber: Ismail, 2012) }
\end{tabular}

Langkah selanjutnya, data-data ordinal tersebut harus diubah ke dalam bentuk data interval, karena data ordinal tersebut sebenarnya adalah data kualitatif dan bukan data sebenarnya. Metode yang umum digunakan untuk mengubah data ordinal menjadi data interval, digunakan Metode Suksesif Interval (Method of Successive Interval/MSI). Kemudian setelah itu, untuk mengetahui efektifitas dari pembelajaran berbasis masalah dengan menggunakan stimulus permasalahan lingkungan global terhadap sikap kepedulian lingkungan siswa, maka dilakukan dengan menghitung rerata nilai dibandingkan dengan nilai KKM serta menghitung indeks gain nya.

\section{Hasil Penelitian}

Berdasarkan hasil penelitian yang telah dilakukan terhadap nilai pretes dan postes dari skala sikap kepedulian lingkungan siswa, menunjukkan bahwa perolehan nilai sikap tertinggi adalah sikap peduli atau sadar dengan nilai 95, sedangkan untuk perolehan nilai sikap yang terendah adalah sikap komitmen dengan nilai 55. Sedangkan untuk perolehan nilai rata-rata seluruh sikap kepedulian lingkungan sis-wa adalah 81,4. Nilai-nilai tersebut secara le-bih jelasnya dituangkan dalam grafik 3.1 berikut ini.

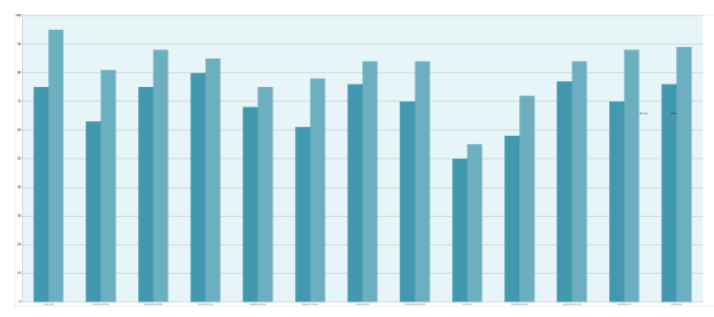

Gambar 3.1

Nilai Pretes dan Postes untuk Masing-masing Sikap Kepedulian Lingkungan Siswa

Kemudian untuk mengetahui efektifitas penggunaan model pembelajaran berbasis masalah dengan memunculkan permasalahan lingkungan global, maka harus dilihat nilai ketuntasan belajar dan nilai indeks gain nya. Dari hasil penelitian, dapat dilihat bahwa nilai rata-ratanya berada pada nilai 81,4 , yang artinya sudah memenuhi Kriteria Ketuntasan Minimal (KKM). Selain itu, nilai indeks gain dari pretes dan postes sebesar 0,52 (sedang). Hal ini dapat disimpulkan bahwa penggunaan model pembelajaran berbasis masalah dengan memunculkan permasalahan lingkungan global, efektif untuk meningkatkan sikap kepedulian lingkungan pada siswa. Untuk lebih jelasnya, nilai indeks gain dari pretes dan postes skala sikap kepedulian lingkungan siswa, disajikan dalam grafik 3.2 di bawah ini.

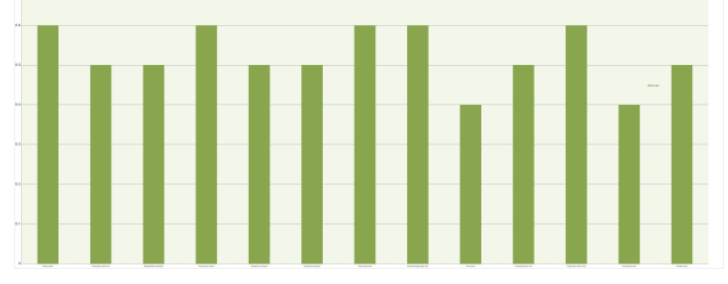

Gambar 3.2

Nilai Indeks Gain untuk Pretes dan Postes Sikap Kepedulian Lingkungan Siswa

Hasil ini menunjukkan bahwa penggunaan model pembelajaran berbasis masalah dengan memunculkan permasalahan 
lingkungan yang sifatnya global, sangat direkomendasikan untuk dilakukan di dalam proses pembelajaran untuk meningkatkan sikap kepedulian lingkungan siswa.

\section{Daftar Pustaka}

Akcay, Behiye. (2009). "Problem Based Learning in Science Education". Journal of Turkish Science Education. 6, (1), 26-36.

Anderson, Lorin. W. dan Krathwohl, D. (2001). A Taxonomy for Learning, Teaching, and Assessing (A Revision of Bloom's Taxonomy of Educational objectives). New York: Longman.

Arends, Richard, I. (2008). Learning to Teach (Belajar untuk Mengajar) Edisi Ketujuh dalam Bahasa Indonesia. Yogyakarta: Pustaka Pelajar.

Arikunto, S. (2009) Dasar-dasar Evaluasi Pendidikan (edisi Revisi). Jakarta: Bumi Aksara.

Berthouex, P.M, dan Brown, L. (2013). Pollution Prevention and Control, $1^{\text {st }}$ edition. Tersedia: www.bookboon.com.

Bilgin, I., E. Senocak, dan M. Sozbilir. (2009). "The Effect of Problem Based Learning Instruction on Students Performance of Conceptual and Quantitative problem in Gas Concepts". Eurasia Journal of Mathematics, Science \& Technology Education, 5 (2), 153-164.

Boediono \& Koster, W. (2004). Teori dan Aplikasi: Statistika dan Probabilitas. Bandung: PT Remaja Rosdakarya

Cahyadi, Ani. (2009). Problem Solving. [online]: tersedia: http:// anicahyadi .blogspot.com /2009/02/problemsolving.html [4 November 2010]

Chin, C. dan L., Chia. (2009). "Implementing Problem Based Learning in Biology". Journal of Biological Education. 38, (2), 69-75.
Dahar, R. W. (1996). Teori-teori Belajar. Jakarta: Penerbit Erlangga.

Delisle, Robert. (1997). How to Use Problem Based Learning in The Classroom. Virginia: Association for Supervision and Curriculum Development (ASCD) Alexandria.

Fraenkel, J.R., Wallen, N.E., dan Hyun, H.H. (2012). How to Design and Evaluate Research in Education: Eight Edition. New York: McGraw-Hill Companies.

Hapsari, D.,S. (2013). Penurunan Keanekaragaman Hayati Ancaman Serius Persediaan Pangan Dunia. [online]. Tersedia: www.food.detik.com. [5 April 2014].

Himpunan Pemerhati Lingkungan Hidup Indonesia. (2011). Isu Lingkungan. [online]. Tersedia:www.hpli.org. [5 April 2014].

Irwanto. (2013). Kerusakan Hutan di Indonesia.[online], tersedia: www. irwantoshut.net. [25Februari 2014].

Ismail. (2012). Analisis Skala Sikap: Sebuah Contoh Prosedur dan Aplikasinya. [online]. Tersedia: www.ismails3ip.fkip.uns.ac.id. [27Februari 2014]

Jones, Clifford, Dr. (2008). Atmospheric Pollution: $1^{\text {st }}$ edition: Tersedia: www.bookboon.com.

Jones, Clifford, Dr. (2013). Global Trends and Patterns in Carbon Mitigation: $1^{\text {st }}$ edition: Tersedia: www. bookboon.com

Karno To. (2004). Mengenal Analisis Tes (Pengantar ke Program Komputer ANATES). Bandung: Jurusan Pendidikan Psikologi dan Bimbingan FIP IKIP Bandung.

Keziah, Achuonye. (2010). "A Comparative Study of Problem Based and Lecture Based Learning in Secondary School Students Motivation to Learn Science”. International Jour- 
nal of Science and Technology Education Research. 1, (6), 126131.

Krathwohl, Bloom, dan Masia. (1964). Taxonomy of Educational Objectives: Affective Domain. New York: Longman.

Natural Resources Defense Council. (2011). An Introduction to Climate Change. [online]: Tersedia: www. nrdc.org. [7 April 2014].

Potters, Geert, Dr. (2013). Marine Pollution: $1^{\text {st }}$ edition. Tersedia: www.bookboon.com.

Priyo, Jatmiko, B.(2013). Pertumbuhan Penduduk Dunia Lampaui Prediksi. [online]. Tersedia: www. kompas.com. [24 Februari 2014].

Rustaman, N. et all (2005) Strategi Belajar Mengajar Biologi. Malang: UM Press.

Schulze, E.D., Beck, E., dan Hohenstein, K.M. (2005). Plant Ecology. Heidelberg: Springer Berlin.

Slameto. (2003). Belajar dan Faktor-faktor yang Mempengaruhinya. Ja-karta: Rineka Cipta.

Solomon, E.P., Berg, L.R., dan Martin, D.W. (2008). Biology: Eight Edition. Belmont: Thomson Brooks /Cole Corporation.
Stiggins, R. J. (1994). Student-centered Classroom Assessment. New York: MacMillan College Publish-ing Company.

Sudjana. (2005). Metoda Statistika. Bandung: Penerbit Tarsito.

Sugiyono. (2010). Metode Penelitian Pendidikan. Bandung: Penerbit Alfabeta.

Suriasumantri, J.S. (2010). Filsafat Ilmu: Sebuah Pengantar Populer. Jakarta: Pustaka Sinar Harapan.

Tan, Oon-Seng. (2006). Problem-Based Learning Pedagogies: Psychological Processes and Enhancement of Intelligences. Singapore: National Institute of Education, Nanyang Technological University.

Wood, D.F. (2003). "Problem Based Learning". $A B C$ of Learning and Teaching in Medicine, vol.326. [online].Tersedia:http://www..bmj. com/content/full/326 /7384/328 [10 Juli 2011]

Yeung E., Chiu T., Mok N., Lai P., (1999). Application of Problem Based Learning Strategies to Enhance Clinical Reasoning and SelfDirected Learning Skills in a University Physiotherapy Program. Department of Rehabilitation Sciences, The Hong Kong Polytechnic University, Hong Kong 